\title{
Hepatitis B vs. hepatitis C infection on viral hepatitis-associated hepatocellular carcinoma
}

\author{
Spiros P Hiotis ${ }^{1,5^{*}}$, Nuh N Rahbari ${ }^{2}$, Gerald A Villanueva ${ }^{3}$, Eunjie Klegar ${ }^{4}$, Wei Luan ${ }^{1}$, Qin Wang ${ }^{1}$ and Herman T Yee ${ }^{4}$
}

\begin{abstract}
Background: To determine clinical-pathologic variables in patients with a new diagnosis of hepatocellular carcinoma (HCC) and underlying hepatitis B vs. C infection.

Methods: Patients presenting to a single urban hospital with a new diagnosis of HCC were entered into a clinical database. Variables including number and size of tumors, presence of metastases, serum alpha-Fetoprotein, hepatitis serologies, severity of hepatic dysfunction, and presence of cirrhosis were evaluated in 127 patients.

Results: Patients with hepatitis B (HBV) were more likely to develop HCC at a younger age than patients with hepatitis C (HCV) (HBV-26\% under age 40, HCV-0\% under age 40; $p<0.001)$, with greater serum alpha-Fetoprotein production (median level: HBV-1000 ng/ml vs. HCV-37 ng/ml; $p=0.002$ ), with larger tumors (HBV-78\% $>5 \mathrm{~cm}, \mathrm{HCV}-28$ $\%>5 \mathrm{~cm} ; \mathrm{p}<0.001)$, in the absence of cirrhosis (HBV-40\%, HCV-0\%; $<<0.001)$, and a decreased eligibility for curative treatment (HBV-14\%, HCV-34\%; $\mathrm{p}<0.05)$. Conversely, patients with HCV were more likely to develop HCC in association with multiple co-morbidities, cirrhosis, and older age.
\end{abstract}

Conclusions: Significant clinical-pathologic differences exist among HCC patients with underlying HBV vs. HCV. These differences impact eligibility for potentially-curative therapy and prognosis.

Keywords: Hepatocellular carcinoma, Hepatitis B, Hepatitis C, Viral hepatitis

\section{Background}

Hepatocellular Carcinoma (HCC) is the third leading cause of cancer related mortality worldwide [1]. The global prevalence and mortality resulting from HCC is directly related to underlying risk factors for primary liver cancer in at-risk populations. Although several chronic liver diseases are associated with HCC, Hepatitis B Virus (HBV) and Hepatitis C Virus (HCV) statistically are the most commonly implicated risk factors. Combined they are responsible for $85 \%$ of total new HCC cases worldwide; $54 \%$ occurring as a result of $\mathrm{HBV}$, and $31 \%$ as a result of $\mathrm{HCV}[2,3]$. HBV, which is endemic in developing geographic regions such as Eastern Asia and SubSaharan Africa, is responsible for up to $90 \%$ of new HCC cases in such areas [4].

Epidemiologic analyses and clinical series which lead to our understanding of the behavior and natural history of

\footnotetext{
* Correspondence: spiros.hiotis@mountsinai.org

'Department of Surgery, Mount Sinai School of Medicine, New York, USA

${ }^{5}$ Division of Surgical Oncology, Mount Sinai School of Medicine, One Gustave L Levy Place, Box 1259, New York, NY 10029, USA

Full list of author information is available at the end of the article
}

HCC do not usually subset results according the underlying viral risk factors for the disease [5]. Most survival analyses from institutions with broad experience in surgical resection, transplantation, ablation, transarterial chemoembolization, or other treatments usually combine patients, irrespective of their underlying viral hepatitis status or association to other risk factors [6,7]. Therefore variations in patterns of presentation, tumor biology, or treatment outcomes for $\mathrm{HCC}$ according to underlying association to viral hepatitis $\mathrm{B}$ or $\mathrm{C}$ remain unclear.

Despite histologic similarities in end-organ damage and eventual carcinomas, adequate scientific rationale supports a proposed hypothesis that distinct pathophysiologic mechanisms may be responsible for hepatocarcinogenesis due to either HBV or HCV. This is based in part on marked virologic differences seen among the 2 pathogens. Hepatitis B is a DNA virus belonging to the Hepadna virus family, which persists in the hepatocyte nucleus predominantly in the form of covalently closed circular DNA (cccDNA), the functional template for viral transcription and replication [8]. Conversely, Hepatitis $\mathrm{C}$ is an RNA virus belonging to the flavivirus family

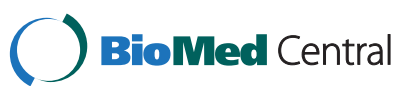


which replicates in the hepatocyte cytoplasm, with a completely distinct life cycle and pattern of viral replication $[9,10]$. Differences in natural history of resulting benign liver disease is well-described among the 2 viruses [11].

In this study, an attempt has been made to evaluate potentially significant clinical-pathologic differences in HCC's that develop in association with chronic HBV vs. $\mathrm{HCV}$. Comparisons have been made among two otherwise comparable groups according to data collected upon initial cancer diagnosis at a single, urban hospital. Demographic data and widely accepted relevant clinicalpathologic features of newly diagnosed HCC's have been collected with the intended purpose of delineating potentially significant differences in cancers which arise in $\mathrm{HBV}$ vs. HCV infected patients.

\section{Methods}

\section{Database enrollment}

Patients were enrolled into a clinical database based upon a diagnosis of HCC at a single New York City public hospital (Bellevue Hospital Center). The database was approved by the IRB of New York University Medical Center and was in compliance with the Helsinki Declaration. The overall period of enrolment spanned the years of 1993 to 2005. Data for patients diagnosed between 1993 and 2001 was collected in a retrospective manner, while data collected between the years of 2001 and 2005 was entered prospectively. This study was exempt from IRB approval according to the institutional criteria at New York University Medical Center. Hence, informed consent was not required for this study.

Demographic data including age, sex, race, and ethnicity were collected. Several clinical-pathologic features were also recorded upon initial HCC diagnosis including the following: tumor size, tumor number, presence of synchronous distant metastases, macro-vascular invasion (tumor thrombus), viral hepatitis serologies, serum biochemistries including liver function tests, serum alphafetoprotein, presence and severity (according to ChildsPugh classification) of coexisting cirrhosis, and underlying co morbidities.

In subsequent retrospective analysis of database variables, patients were stratified according to underlying risk factors for HCC. In order to facilitate a cohort comparison of HBV vs. HCV as risk factors for cancer, patients with either HBV or HCV only were included for analysis. Those co-infected both with HBV and HCV, or neither hepatitis virus were excluded from this analysis.

\section{Diagnosis of HCC}

The diagnosis of HCC was based upon histology or cytology, when tissue was available following surgical resection or biopsy. For cases in which no tissue was available, patients were diagnosed with $\mathrm{HCC}$ if dynamic imaging findings (CT with intravenous contrast or MRI only) of a hypervascular solid liver mass with features characteristic for HCC were present in a setting of underlying risk factors, along with a clearly elevated serum alpha-fetoprotein $(>100 \mathrm{ng} / \mathrm{ml})$. A diagnosis of HCC for all patients that presented with non-AFPproducing tumors was confirmed by biopsy. Of all 127 patients, 76 (60\%) were diagnosed based upon histology or cytology, while $51(40 \%)$ were diagnosed with imaging along with other features.

\section{Diagnosis of cirrhosis}

A diagnosis of cirrhosis was made based on a combination of clinical parameters. For patients in whom tissue (from biopsy of resection specimens) was available from the non-neoplastic liver, a diagnosis of cirrhosis was made if histologic findings of hepatic fibrosis were observed in conjunction with clinical evidence of severe hepatic dysfunction (such as hypoalbuminemia). Patients with available histologic specimens demonstrating no evidence of hepatic fibrosis were deemed non-cirrhotic. For patients in whom non-neoplastic liver tissue was unavailable, a diagnosis of cirrhosis was based upon a combination of axial imaging features (including hepatic macronodularity and ascites), serum biochemistries indicative of severe hepatic dysfunction (such as hypoalbuminemia), and physical exam findings such as documented ascites.

\section{Statistical analyses}

Comparisons of patient cohorts were performed using Fisher's exact test. A p value of $<0.05$ was used to designate a statistically significant difference among observed vs. expected outcomes.

\section{Results}

\section{Demographics, age distribution, and underlying} comorbidities

A total of 149 HCC patients were enrolled during the study period: $89(59.7 \%)$ with $\mathrm{HBV}$-associated cancers, 38 (25.5\%) with $\mathrm{HCV}$-associated cancers, 4 (2.7\%) with cancers associated with both $\mathrm{HBV}$ and $\mathrm{HCV}$, and 18 patients $(12.1 \%)$ with cancers not associated with either hepatitis virus (Figure 1). HCC patients with HBV and $\mathrm{HCV}$ co-infection, as well as those without underlying viral hepatitis were excluded from the present analysis. HCC developed more commonly among males in both groups, however the association to male gender was stronger in the HBV group. Only 5\% of HBV-associated HCC's developed in female patients compared with $21 \%$ of HCV-associated HCC's ( $p=0.007$, Table 1). The majority of $\mathrm{HBV}$-associated $\mathrm{HCC}$ patients were of Asian 


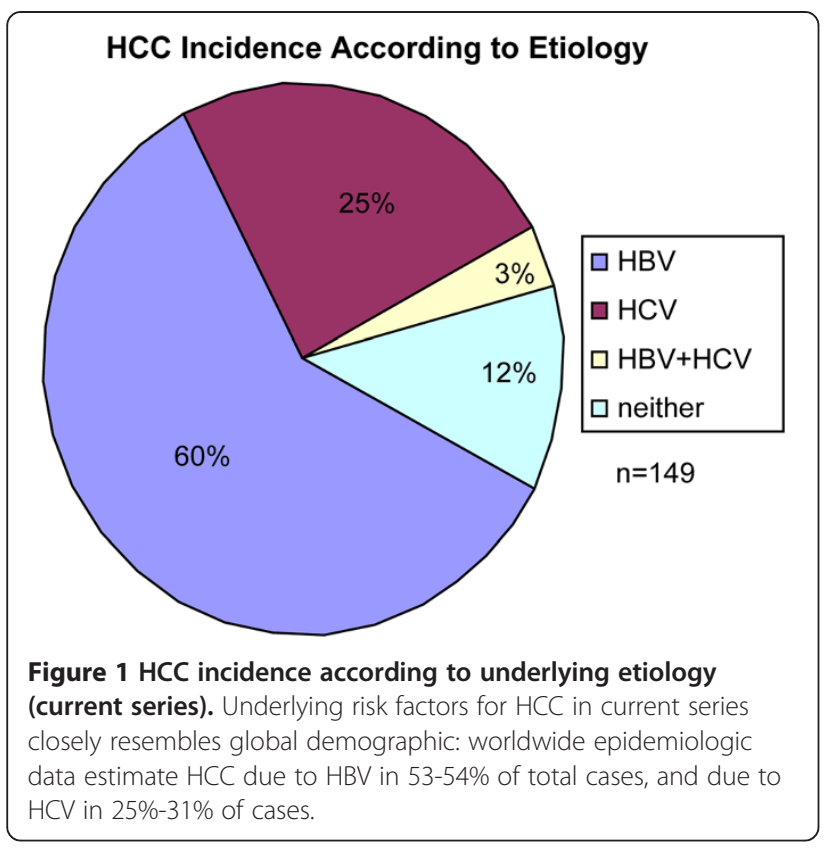

race $(90 \%)$, compared with only $5 \%$ in $\mathrm{HCV}$-associated HCC patients $(\mathrm{p}<0.001$, Table 1$)$.

The median age upon initial diagnosis for patients with either HBV or HCV-associated HCC's was similar (HBV, 50 years; $\mathrm{HCV}, 58$ years); however, the age distribution in the two groups differed considerably. Approximately one fourth $(26 \%)$ of all HBV-associated HCC's occurred in patients aged 40 years or younger, while no cancers developed in patients under the age of 40 in the $\mathrm{HCV}$ group ( $<<0.001$, Table 1$)$. In fact, only 2 HCC's $(5 \%)$ occurred in the HCV group at 50 years of age or less. This contrasted with the HBV group, in whom nearly half $(49 \%)$ of cancers had already occurred by the age of 50 (Table 1).

As a group, patients who developed HCC associated with underlying HBV had fewer systemic comorbidities than those with underlying $\mathrm{HCV}$. A mean of 1.0 underlying systemic comorbidity was present in HBV patients at the time of initial cancer diagnosis, compared with a mean of 2.9 associated systemic comorbidities in $\mathrm{HCV}$ patients (Table $1, \mathrm{p}<0.001$ ). A coincident history of alcohol abuse was also less frequent in the HBV group (7\% in $\mathrm{HBV}$ vs. $32 \%$ in $\mathrm{HCV}, \mathrm{p}<0.001$ ), as was the frequency of HIV co-infection ( $1 \%$ in HBV vs. $13 \% \mathrm{HCV}$, $\mathrm{p}<0.001)$.

\section{Co-existence of cirrhosis in the non-neoplastic liver}

Patients with underlying HBV were less likely to have developed cirrhosis at the time of progression to cancer compared with patients with underlying HCV ( $\mathrm{p}<0.001$, Table 1). Without exception, all patients who developed $\mathrm{HCC}$ in a setting of chronic HCV had established cirrhosis at the time of initial cancer diagnosis. However,
Table 1 Demographic and clinical-pathologic comparisons of patients with HCC associated with underlying $\mathrm{HBV}$ vs. those with $\mathrm{HCV}$-associated $\mathrm{HCC}$

\begin{tabular}{|c|c|c|c|c|}
\hline & $\begin{array}{l}\text { All } \\
(n=127)\end{array}$ & $\begin{array}{l}\text { HBV } \\
(n=89)\end{array}$ & $\begin{array}{l}\text { HCV } \\
(n=38)\end{array}$ & $\mathrm{P}$ value $†$ \\
\hline \multicolumn{5}{|l|}{ Gender } \\
\hline Male & $115(90 \%)$ & $85(95 \%)$ & $30(79 \%)$ & $p=0.007$ \\
\hline Female & $12(10 \%)$ & $4(5 \%)$ & $8(21 \%)$ & \\
\hline \multicolumn{5}{|l|}{ Race } \\
\hline Asian & 82 (65\%) & 80 (90\%) & $2(5 \%)$ & $p<0.001$ \\
\hline Non-Asian & $45(35 \%)$ & $9(10 \%)$ & $36(95 \%)$ & \\
\hline \multicolumn{5}{|l|}{ Age } \\
\hline Median & 53 & 50 & 58 & NS \\
\hline Range & $21-79$ & $21-75$ & $47-79$ & \\
\hline \multicolumn{5}{|l|}{ Distribution } \\
\hline $21-30$ & $5(4 \%)$ & $5(6 \%)$ & $0(0 \%)$ & \\
\hline $31-40$ & $18(14 \%)$ & $18(20 \%)$ & $0(0 \%)$ & $p<0.001 \ddagger$ \\
\hline $41-50$ & $23(18 \%)$ & $21(24 \%)$ & $2(5 \%)$ & \\
\hline $51-60$ & 50 (39\%) & $28(31 \%)$ & $22(58 \%)$ & \\
\hline$>60$ & $31(24 \%)$ & $17(19 \%)$ & $14(37 \%)$ & \\
\hline \multicolumn{5}{|l|}{ Comorbidities } \\
\hline Mean \pm S.D & $1.6 \pm 1.6$ & $1.0 \pm 1.1$ & $2.9 \pm 1.5$ & $p<0.001$ \\
\hline \multicolumn{5}{|l|}{ Alcohol abuse } \\
\hline & $18(15 \%)$ & $6(7 \%)$ & $12(32 \%)$ & $p<0.001$ \\
\hline \multicolumn{5}{|l|}{ HIV coinfection } \\
\hline & $8(6 \%)$ & $1(1 \%)$ & $7(13 \%)$ & $p<0.001$ \\
\hline \multicolumn{5}{|c|}{ Cirrhosis state in the non-neoplastic liver $(n=119)$} \\
\hline Non-cirrhosis & $34(29 \%)$ & $34(40 \%)$ & $0(0 \%)$ & $p<0.001$ \\
\hline Cirrhosis & $85(71 \%)$ & $50(60 \%)$ & $35(100 \%)$ & \\
\hline \multicolumn{5}{|c|}{ AFP levels $(n=122)$} \\
\hline Median & 137 & 1000 & 37 & $p=0.002$ \\
\hline Range & $3-871,485$ & $3-871,485$ & $4-59,739$ & \\
\hline \multicolumn{5}{|l|}{ Distribution } \\
\hline$\leq 9$ & $20(16 \%)$ & $13(15 \%)$ & $7(19 \%)$ & NS * \\
\hline $9-20$ & $10(8 \%)$ & 7 (8\%) & $3(8 \%)$ & NS * \\
\hline $20-100$ & 27 (22\%) & $10(12 \%)$ & 17 (46\%) & $\mathrm{p}<0.001 *$ \\
\hline $100-1,000$ & $15(12 \%)$ & $11(13 \%)$ & $4(11 \%)$ & $p<0.001 *$ \\
\hline $1,000-10,000$ & 27 (22\%) & $23(27 \%)$ & $4(11 \%)$ & $p=0.01 *$ \\
\hline$>10,000$ & 23 (19\%) & $21(25 \%)$ & $2(5 \%)$ & \\
\hline
\end{tabular}

$+P$ values were obtained by Fisher's exact test, two-tailed $t$ test or nonparametric Mann-Whitney U test.

$\pm \mathrm{p}<0.001$ when comparing HCC developing under age 40 in HBV vs. HCV

${ }^{*} \mathrm{p}$ values obtained when comparing distribution with AFP cut-off at 9, 20, $100,1,000$, or 10,000 in HBV vs. HCV. NS: not significant.

$40 \%$ of patients with underlying HBV developed $\mathrm{HCC}$ in the absence of cirrhosis. When HCC patients with established cirrhosis due to either $\mathrm{HBV}$ or $\mathrm{HCV}$ were compared, the severity of cirrhosis as determined by the Childs-Pugh classification, was similarly distributed in both viral hepatitis groups. 


\section{Alpha-fetoprotein production}

A significant difference in serum alpha-fetoprotein (AFP)production was observed in HCC's associated with underlying $\mathrm{HBV}$ as opposed to those associated with $\mathrm{HCV}$ (Table 1). The median level of serum AFP in HBVassociated $\mathrm{HCC}$ was greater than $\mathrm{HCV}$-associated $\mathrm{HCC}$ $(1000 \mathrm{ng} / \mathrm{ml}$ vs. $37 \mathrm{ng} / \mathrm{ml}, \mathrm{p}=0.002)$. While the proportion of patients with normal level of serum AFP $(<20 \mathrm{ng} / \mathrm{ml})$ was similar between HBV- and HCV-associated HCC, the proportion of $\mathrm{HCC}$ producing higher amount of AFP $(>100 \mathrm{ng} / \mathrm{ml}$ ) was greater in HBV-associated HCC. Sixty five percent of HBV-associated $\mathrm{HCC}$, in contrast to only $27 \%$ of HCV-associated HCC, produced AFP greater than $100 \mathrm{ng} / \mathrm{ml}(\mathrm{p}<0.001)$. Similarly, the proportion of HBVassociated HCC producing AFP greater than $1,000 \mathrm{ng} / \mathrm{ml}$ or $10,000 \mathrm{ng} / \mathrm{ml}$ was higher compared with $\mathrm{HCV}$ associated HCC ( $52 \%$ vs. $16 \%$, and $25 \%$ vs. $5 \%$, respectively, Table 1).

\section{Oncologic prognostic variables}

The presence upon initial cancer diagnosis of several well established oncologic variables associated with a poor cancer specific prognosis was assessed according to underlying viral hepatitis status. These include tumor size, tumor number, macrovascular invasion, and the presence of synchronous distant metastases.

Patients with HBV-associated HCC were significantly more likely to be diagnosed with larger tumors, than those with $\mathrm{HCV}$-associated HCC. Seventy eight percent of $\mathrm{HBV}$-associated tumors exceeded $5 \mathrm{~cm}$ in greatest cross-sectional diameter, as compared with only $28 \%$ of those associated with HCV ( $<0.001$, Table 2). Analysis of all other selected variables failed to demonstrate a significant difference according to viral hepatitis status. Multifocal tumors and macrovascular invasion occurred with similar frequency in both the $\mathrm{HBV}$ and $\mathrm{HCV}$

Table 2 Indicators of poor prognosis and their association with underlying viral hepatitis status

\begin{tabular}{clll}
\hline & HBV & HCV & P value \\
\hline Tumor Size $(n=122)$ & & & \\
\hline$<5 \mathrm{~cm}$ & $19(22 \%)$ & $23(61 \%)$ & \\
\hline$>5 \mathrm{~cm}$ & $66(78 \%)$ & $14(28 \%)$ & $\mathrm{p}<0.001$ \\
\hline Tumor Number $(\mathrm{n}=122)$ & & & \\
\hline solitary & $43(51 \%)$ & $17(46 \%)$ & \\
\hline multiple & $42(49 \%)$ & $20(54 \%)$ & $\mathrm{NS}$ \\
\hline Synchronous Metastases $(\mathrm{n}=116)$ & & & \\
\hline absent & $71(85 \%)$ & $30(94 \%)$ & \\
\hline present & $13(15 \%)$ & $2(6 \%)$ & $\mathrm{NS}$ \\
\hline Macro-Vascular Invasion $(\mathrm{n}=117)$ & & & \\
\hline absent & $57(69 \%)$ & $26(76 \%)$ & \\
\hline present & $26(31 \%)$ & $8(24 \%)$ & NS \\
\hline
\end{tabular}

groups (HBV- $49 \%$ vs. HCV-54\% and HBV-31\% vs. HCV$24 \%$, respectively). The incidence of synchronous distant metastases was observed with double the frequency in $\mathrm{HBV}$ patients, when compared to those with $\mathrm{HCV}$ (HBV-15\% vs. HCV-6\%). However, this trend did not achieve statistical significance, likely due to statistical underpowering of the study at the current sample size.

\section{Eligibility for treatment with curative intent}

Eligibility for liver transplantation and surgical resection with expected favorable long-term survival, according to underlying viral hepatitis status, was determined by application of the Milan criteria [12,13]. Patients with $\mathrm{HBV}$-associated cancers were far less likely to meet these criteria upon initial HCC diagnosis than were those with $\mathrm{HCV}$-associated cancers ( $14 \%$ vs. $34 \%$, respectively, p $<0.05$ ). This more commonly precluded treatment with expectation for cure in patients with $\mathrm{HBV}$-associated $\mathrm{HCC}$, when compared to patients with HCV.

\section{Discussion}

Viral Hepatitis B and Hepatitis C are the most commonly implicated risk factors for $\mathrm{HCC}$, with $\mathrm{HBV}$ responsible for the majority of cases worldwide. The epidemiologic predominance of $\mathrm{HBV}$-associated $\mathrm{HCC}$ worldwide is largely due to the endemic nature of HBV infection in East Asian and subsaharan African populations [14]. Given the broad ethnic and racial diversity of patients seen at the single New York institution from which data was collected (Bellevue Hospital Center), patients included in the current analysis closely resemble the global demographic for HCC [2,3]. Sixty percent of all HCC cases were due to underlying HBV, and $25 \%$ were due to HCV. The majority of patients in the HBV group were of East Asian race (90\%), compared to only $5 \%$ in the HCV group. This statistic potentially explains the significant disparity in age at initial cancer diagnosis among HBV vs. HCV-infected patients. HBV transmission in East Asian populations predominantly follows vertical (maternal-fetal) patterns of transmission [15]. In contrast, HBV in non-Asian populations, and HCV are more frequently transmitted in horizontal patterns as a result of exposure to infected body fluids [16-18]. Thus HCV exposure usually occurs later in life compared to HBV in the largest worldwide at risk populations. This finding from our study is consistent with previous studies in Japan showing younger detection age in HBV HCC patients compared with HCV HCC patients $[19,20]$. Although the mechanistic sequence of events required for progression from chronic viral hepatitis infection to HCC are poorly understood, a reasonable conclusion based on the current data could imply that the young age associated with HBV-HCC occurs as a direct result of vertical HBV transmission. Thus screening for 
HCC in patient populations known to be at risk for vertically-transmitted HCC should begin at an early age, no later than early adulthood.

Another important difference in the progression to $\mathrm{HCC}$ among HBV vs. HCV infected patients is the association to pre-existing cirrhosis at the time of initial cancer diagnosis. The occurrence of HCC in the absence of cirrhosis in a substantial percentage of HBV-HCC patients $(40 \%)$, compared to the invariable association to established cirrhosis in those with HCV-HCC, suggests a potential cirrhosis-independent pathway to cancer unique (among viral hepatitis-associated cancers) to HBV-HCC. Much of the literature suggests a generally accepted common pathway to hepatocarcinogenesis, proposed in both HBV and HCV patients, based on: active viral replication, chronic hepatocellular necroinflammatory activity, hepatic parenchymal fibrosis, cirrhosis, and eventually cancer [21-23]. Although this model appears valid for patients with $\mathrm{HCV}$, some with $\mathrm{HBV}$ do not experience such a predictable sequence of events prior to developing liver cancer [24-26].

Considerations relevant to the care of patients who are subject to a cirrhosis-independent pathway to HCC should lead to proposed changes in current widelyadopted practices of screening for $\mathrm{HCC}$ in patients with chronic HBV [27-29]. Proposed changes in surveillance practices, particularly in those suspected of perinatal infection, should include a high level of vigilance for cancer even in the absence of cirrhosis. Several levels of evidence, in addition to the current data, reinforce that HBV patients are at risk for HCC even prior to the development of cirrhosis. Thus HCC screening should not be withheld until evidence of active hepatocellular necroinflammation or cirrhosis are observed.

Several additional significant clinical-pathologic differences in HCC were also observed according to underlying viral hepatitis status, including AFP production. This observation is particularly interesting, given that the utility of serum AFP as a cancer screening tool has been the subject of considerable recent debate, leading some experts in the field to not advocate its use as a tumor marker [30]. In the current study, median AFP level in $\mathrm{HCV}$-associated $\mathrm{HCC}$ was $37 \mathrm{ng} / \mathrm{ml}$, compared with $1000 \mathrm{ng} / \mathrm{ml}$ in HBV-associated HCC, and only 27\% among HCV-associated cancers produced serum AFP greater than $100 \mathrm{ng} / \mathrm{ml}$, compared with $65 \%$ in of HBVassociated HCC. This result suggests a higher sensitivity of serum AFP as a tumor marker when used in patients with $\mathrm{HBV}$, but maybe less so in screening patients with $\mathrm{HCV}$ for cancer.

Oncologic variables with established prognostic significance were evaluated according to viral hepatitis status. Both macrovascular invasion and synchronous metastases occurred with greater frequency in the HBV-HCC group, although these observations did not achieve statistical significance. Only tumor size on initial HCC diagnosis, an important prognostic indicator, was statistically different among HBV vs. HCV patients [31-33]. This tumor size discrepancy may be explainable by less rigorous cancer screening recommendations for patients with chronic HBV, compared to more uniform and frequent screening programs for patients with $\mathrm{HCV}[34,35]$. Many of the accrued HBV-HCC patients would not have met current American Association for the Study of Liver Diseases (AASLD) guidelines for HCC screening due to their young age, absence of cirrhosis or other variables [30]. Thus a relatively delayed cancer diagnosis may be attributable in part to under screening of HBV patients for HCC, when compared to those with chronic $\mathrm{HCV}$.

Often due to initial presentation with large tumors, patients in the HBV-HCC group were less likely to meet Milan eligibility criteria for liver transplantation (single tumor $<5 \mathrm{~cm}$ in greatest diameter or multiple tumor each $<3 \mathrm{~cm}$ in greatest diameter) [12]. Due to the similar prognostic importance of applying Milan criteria to surgical resection series, this association to larger tumors also predicted a lower likelihood of surgical resection with expected favorable long term survival $[13,36,37]$. Overall a staggeringly small fraction of all patients with HCC associated with either hepatitis virus met Milan criteria, underscoring the fact that most patients $(80 \%)$ cannot be treated with the two most effective treatments or an expectation for favorable long term outcome. However, despite this observation in both viral hepatitis patients, inoperable or poor prognosis cancers were significantly more common in patients with HBV. Whether HBV or HCV viral etiology is an independent prognostic factor in patients with $\mathrm{HCC}$ following surgical resection or liver transplantation remains controversial and requires further investigation [38-42].

\section{Conclusions}

In summary, patients with HBV-associated HCC were more likely to present with poor-prognosis cancers, often at a young age, and in the absence of cirrhosis. In contrast, patients with $\mathrm{HCV}$-associated $\mathrm{HCC}$ often were diagnosed in a setting of pre-existing cirrhosis, with multiple comorbidities, but with more favorable oncologic features. These data suggest a role for more aggressive screening and management of chronic HBV patients, particularly those subjected to maternal-fetal viral transmission. The importance of earlier screening and more aggressive treatment is especially emphasized by the advanced oncologic nature of $\mathrm{HCC}$ associated with HBV on typical initial diagnosis. 


\section{Abbreviations}

HCC: Hepatocellular carcinoma; HBV: Hepatitis B; cccDNA: Covalently closed circular DNA; AFP: Alpha-fetoprotein; AASLD: American Association for the Study of Liver Diseases.

\section{Competing interests}

The authors declare that they have no competing interests.

\section{Acknowledgments}

This study is supported by a research grant from Gilead Sciences, Inc

\section{Author details}

${ }^{1}$ Department of Surgery, Mount Sinai School of Medicine, New York, USA ${ }^{2}$ Department of Surgery, University of Heidelberg, Heidelberg, Germany. ${ }^{3}$ Department of Gastroenterology, Bellevue Hospital / NYU, New York, USA. ${ }^{4}$ Department of Pathology, Bellevue Hospital / NYU, New York, USA. ${ }^{5}$ Division of Surgical Oncology, Mount Sinai School of Medicine, One Gustave L Levy Place, Box 1259, New York, NY 10029, USA

\section{Authors' contributions}

SPH conceived of, designed and supervised the study and drafted the manuscript. NNR participated in data acquisition, GAV participated in data acquisition, EK participated in data acquisition, WL participated in data entry and acquisition, QW participated in data analysis and manuscript writing, HTY performed histological analysis. All authors read and approved the final manuscript.

Received: 24 February 2012 Accepted: 8 June 2012

Published: 8 June 2012

\section{References}

1. Parkin DM, Bray Fl, Devesa SS: Cancer burden in the year 2000. The global picture. Eur J Cancer 2001, 37(Suppl 8):S4-S66.

2. Parkin DM: The global health burden of infection-associated cancers in the year 2002. Int J Cancer 2006, 118:3030-3044.

3. Perz JF, Armstrong GL, Farrington LA, Hutin YJF, Bell BP: The contributions of hepatitis $B$ virus and hepatitis $C$ virus infections to cirrhosis and primary liver cancer worldwide. J Hepatol 2006, 45:529-538.

4. Raza SA, Clifford GM, Franceschi S: Worldwide variation in the relative importance of hepatitis $B$ and hepatitis $C$ viruses in hepatocellular carcinoma: a systematic review. Br J Cancer 2007, 96:1127-1134.

5. Varela M, Sala M, Llovet JM, Bruix J: Review article: natural history and prognostic prediction of patients with hepatocellular carcinoma. Aliment Pharmacol Ther 2003, 17(Suppl 2):98-102.

6. Lopez PM, Villanueva A, Llovet JM: Systematic review: evidence-based management of hepatocellular carcinoma-an updated analysis of randomized controlled trials. Aliment Pharmacol Ther 2006, 23:1535-1547.

7. Bruix J, Sherman M, Llovet JM, Beaugrand M, Lencioni R, Burroughs AK, Christensen E, Pagliaro L, Colombo M, Rodés J, EASL Panel of Experts on HCC: Clinical management of hepatocellular carcinoma. Conclusions of the Barcelona-2000 EASL Conference. J Hepatol 2001, 35:421-430.

8. Beck J, Nassal M: Hepatitis B virus replication. World J Gastroenterol 2007, 13:48-64.

9. Pawlotsky JM, Chevaliez S, McHutchison JG: The hepatitis C virus life cycle as a target for new antiviral therapies. Gastroenterology 2007, 132:1979-1998.

10. Moradpour D, Penin F, Rice CM: Replication of hepatitis C virus. Nat Rev Microbiol 2007, 5:453-463.

11. Rehermann B, Nascimbeni M: Immunology of hepatitis B virus and hepatitis C virus infection. Nat Rev Immunol 2005, 5:215-229.

12. Mazzaferro V, Regalia E, Doci R, Andreola S, Pulvirenti A, Bozzetti F, Montalto F, Ammatuna M, Morabito A, Gennari L: Liver transplantation for the treatment of small hepatocellular carcinomas in patients with cirrhosis. $N$ Engl J Med 1996, 334:693-699.

13. Cha $C H$, Ruo L, Fong $Y$, Jarnagin WR, Shia J, Blumgart LH, DeMatteo RP: Resection of hepatocellular carcinoma in patients otherwise eligible for transplantation. Ann Surg 2003, 238:315-321.

14. Shepard CW, Simard EP, Finelli L, Flore AE, Bell BP: Hepatitis B virus infection: Epidemiology and vaccination. Epidemiologic Reviews 2006, 28:112-125.
15. Custer B, Sullivan SD, Hazlet TK, Iloeje U, Veenstra DL, Kowdley KV: Global epidemiology of hepatitis B virus. J Clin Gastroenterol 2004, 38:S158-S168.

16. Deuffic-Burban S, Abiteboul D, Lot F, Branger M, Bouvet $E$, Yazdanpanah Y: Costs and cost-effectiveness of different follow-up schedules for detection of occupational hepatitis C virus infection. Gut 2009, 58(1):105-110

17. Thomson EC, Main J: Epidemiology of Hepatitis $C$ virus infection in HIVinfected individuals. Journal of Viral Hepatitis 2008, 15(1):773-781.

18. Santantonio T, Wiegand J, Gerlach JT: Acute Hepatitis C: Current status and remaining challenges. J Hepatol 2008, 49(4):625-633.

19. Tanizaki H, Ryu M, Kinoshita T, Kawano N, Konishi M, Cho A, Nakatsura T, Natsume T, Takahashi S, Sugita M, Izuishi K, Yoshino M, Furuse J, Iwasaki M, Tsubono $Y$ : Comparison of clinical features and survival in patients with hepatitis B and C virus-related hepatocellular carcinoma. Jpn J Clin Oncol 1997, 27(2):67-70

20. Shiratori $Y$, Shiina S, Imamura M, Kato N, Kanai F, Okudaira T, Teratani T, Tohgo G, Toda N, Ohashi M, Ogura K, Niwa Y, Kawabe T, Omata M: Characteristic difference of hepatocellular carcinoma between hepatitis B- and C- viral infection in Japan. Hepatology 1995, 22(4 Pt 1):1027-1033.

21. Blanc $P$, Desprez D, Fabre JM, Pageaux G, Daures JP, Larrey $D$, SaintAubert B, Michel $H$, Maurel P: Contribution of primary cultures of adult human hepatocytes to the pathophysiology of hepatocellular carcinoma. J Hepatol 1996, 25(5):663-669.

22. Schuppan D, Afdhal NH: Liver cirrhosis. Lancet 2008, 371(9615):838-851.

23. Rosenthal P: Hepatocarcinoma in viral and metabolic liver disease. $J$ Pediatr Gastroenterol Nutr 2008, 46(4):370-375.

24. Kumar M, Kumar R, Hissar SS, Saraswat MK, Sharma BC, Sakhuja P, Sarin SK: Risk factors analysis for hepatocellular carcinoma in patients with and without cirrhosis: A case-controlled study of 213 hepatocellular carcinoma patients from India. J Gastroenterol Hepatol 2007, 22(7):1104-1111.

25. Chen $\mathrm{CH}$, Eng HL, Lee CM, Kuo FY, Lu SN, Huang CM, Tung HD, Chen $\mathrm{CL}$, Changchien CS: Correlations between hepatitis B virus genotype and cirrhotic or non-cirrhotic hepatoma. Hepato-Gatroenterology 2004, 51(56):525-555.

26. Grando-Lemaire V, Guettier C, Chevret S, Beaugrand M, Trinchet JC: Hepatocellular carcinoma without cirrhosis in the West: epidemiological factors and histopathology of the non-tumorous liver. J Hepatol 1999, 31 (3):508-513.

27. Lin SY, Chang ET, So SK: Why we should routinely screen Asian American adults for hepatitis B: A cross-sectional study of Asians in California. Hepatology 2007, 46(4):1034-1040

28. Davila JA, Weston A, Smalley W, El-Serag HB: Utilization of screening for hepatocellular carcinoma in the United States. J Clin Gastroenterol 2007. 41(8):777-782

29. Yamazaki Y, Kakizaki S, Sohara N, Sato K, Takagi H, Arai H, Abe T, Katakai K, Kojima A, Matsuzaki Y, Mori M: Hepatocellular carcinoma in young adults: The clinical characteristics, prognosis, and findings of a patient survival analysis. Dig Dis Sci 2007, 52(4):1103-1107.

30. Bruix J, Sherman M: Management of hepatoceullular carcinoma. Hepatology 2005, 42:1208-1236

31. Martins A, Cortez-Pinto H, Marques-Vidal P, Mendes N, Silva S, Fatela N, Gloria H, Marinho R, Tavora I, Ramalho F, de Moura MC: Treatment and prognostic factors in patients with hepatocellular carcinoma. Liver Int 2006, 26(6):680-687.

32. Llovet JM, Bru C, Bruix J: Prognosis of hepatocellular carcinoma: The BCLC staging classification. Seminars in Liver Disease 1999, 19(3):329-338

33. Bruix J, Sherman M, Llovet JM, Beaugrand M, Lencioni R, Burroughs AK, Christensen E, Pagliaro L, Colombo M, Rodes J: Clinical angement of hepatocellular carcinoma. Conclusions of the Barcelona-2000 EASL conference. J Hepatol 2001, 35(3):421-430.

34. Chalasani N, Horlander JC, Said A, Hoen H, Kopecky KK, Stockberger SM, Manam R, Now PY, Lumeng L: Screening for hepatocellular carcinoma in patients with advanced cirrhosis. Am J Gastroenterol 1999, 94(10):2988-2993.

35. Patel D, Terrault NA, Yao FY, Bass NM, Ladabaum U: Cost-effectiveness of hepatocellular carcinoma surveillance in patients with hepatitis $C$ virusrelated cirrhosis. Clin Gastroenterol Hepatol 2006, 3(1):75-84.

36. Morioka D, Tanaka K, Matsuo K, Takeda K, Ueda M, Sugita M, Nagano Y, Endo I, Sekido H, Togo S, Shimada H: Applicability of the Milan criteria for 
determining liver transplantation as a first-line treatment for hepatocellular carcinoma. Ann Surg Oncol 2006, 13:1500-1510.

37. Margarit C, Escartin A, Castells L, Vargas V, Allende E, Bilbao I: Resection for hepatocellular carcinoma is a good option in Child-Turcotte-Pugh class A patients with cirrhosis who are eligible for liver transplantation. Liver Transpl 2005, 11:1242-1251.

38. Roayaie S, Haim MB, Emre S, Fishbein TM, Sheiner PA, Miller CM, Schwartz ME: Comparison of surgical outcomes for hepatocellular carcinoma in patients with hepatitis B versus hepatitis C: a western experience. Ann Surg Oncol 2000, 7(10):764-770

39. Huang YH, Wu JC, Chen CH, Chang TT, Lee PC, Chau GY, Lui WY, Chang FY, Lee SD: Comparison of recurrence after hepatic resection in patients with hepatitis B vs. hepatitis C-related small hepatocellular carcinoma in hepatitis B virus endemic area. Liver Int 2005, 25(2):236-241.

40. Li Q, Li H, Qin Y, Wang PP, Hao X: Comparison of surgical outcomes for small hepatocellular carcinoma in patients with hepatitis $B$ versus hepatitis C: a Chinese experience. J Gastroenterol Hepatol 2007, 22(11):1936-1941.

41. Ahmad SA, Bilimoria MM, Wang X, Izzo F, Delrio P, Marra P, Baker TP, Porter GA, Ellis LM, Vauthey JN, Dhamotharan S, Curley SA: Hepatitis B or C virus serology as a prognostic factor in patients with hepatocellular carcinoma. J Gastrointest Surg 2001, 5(5):468-476.

42. Kao WY, Su CW, Chau GY, Lui WY, Wu CW, Wu JC: A Comparison of Prognosis between Patients with Hepatitis B and C Virus-related Hepatocellular Carcinoma Undergoing Resection Surgery. World I Surg. 2011, 35(4):858-867.

doi:10.1186/1471-230X-12-64

Cite this article as: Hiotis et al:: Hepatitis B vs. hepatitis C infection on viral hepatitis-associated hepatocellular carcinoma. BMC Gastroenterology 2012 12:64.

\section{Submit your next manuscript to BioMed Central and take full advantage of:}

- Convenient online submission

- Thorough peer review

- No space constraints or color figure charges

- Immediate publication on acceptance

- Inclusion in PubMed, CAS, Scopus and Google Scholar

- Research which is freely available for redistribution 